\title{
PHYSICAL PROPERTIES OF PROTEIN EXTRACT POWDER FROM STALE BREAD AND EVALUATION OF ITS USE IN WHEAT BREAD CONTAINING CHICKPEA FLOUR
}

\author{
Sebahat Sisman, Busra Yagci, Ertan Ermis* \\ İstanbul Sabahattin Zaim University, Faculty of Engineering and Natural Sciences, Food Engineering \\ Department, İstanbul, Turkey
}

Received / Geliş: 13.02.2020; Accepted / Kabul: 12.01.2022; Published online / Online bask1: 26.01.2022

Sisman, S., Yagci, B., Ermis, E. (2022). Physical properties of protein extract powder from stale bread and evaluation of its use in wheat bread containing chickpea flour. GIDA (2022) 47 (1) 34-41 doi: 10.15237/gida.GD21037.

Sisman, S., Yagci, B., Ermis, E. (2022). Bayat ekmekten elde edilen protein ekstrakt tozunun fiziksel özellikleri ve nohut unu içeren buğday ekmeğinde kullanımının değerlendirilmesi. GIDA (2022) 47 (1) 34-41 doi: 10.15237/gida.GD21037.

\begin{abstract}
In this study, it was aimed to investigate the physical properties of protein extract powder from stale bread and its potential use in chickpea flour added wheat bread formulations. Chickpea flour was added into wheat flour at a 2:3 ratio, and the protein extract at $6.5 \%$ and $13 \%$ of total flour mix $(\mathrm{w} / \mathrm{w})$. The moisture content and water activity of the powdered protein extract were $5.55 \%$ and 0.58 , respectively. The bulk density and tapped density were $830 \mathrm{~kg} \cdot \mathrm{m}^{-3}$ and $910 \mathrm{~kg} \cdot \mathrm{m}^{-3}$, respectively. Hausner ratio was measured as 1.10 , which indicates free-flowing property. Increasing the addition of protein extract from $6.5 \%$ to $13 \%$ resulted in increased loaf volume from around $283 \mathrm{~mL}$ to $307 \mathrm{~mL}$ per loaf.

Keywords: Loaf volume, chickpea flour, FTIR, protein powder

\section{BAYAT EKMEKTEN ELDE EDİLEN PROTEİN EKSTRAKT TOZUNUN FİZİKSEL ÖZELLİKLERİ VE NOHUT UNU İÇEREN BUĞDAY EKMEĞİNDE KULLANIMININ DEĞERLENDİRILLMESİ}

\section{ÖZ}

Bu çalışmada, bayat ekmekten elde edilen protein ekstraktı tozunun fiziksel özelliklerinin ve nohut unu katkılı buğday ekmeği formülasyonlarında potansiyel kullanımının araştırılması amaçlanmıştır. Nohut unu, buğday ununa 2:3 oranında ve protein ekstraktı tozu toplam un karışımının ağırlıkça \% 6.5 ve 13 'ü oranında ilave edilmiştir. Toz protein ekstraktının nem içeriği ve su aktivitesi sırasıyla \% 5.55 ve 0.58 olarak bulunmuştur. Yığın yoğunluğu ve sıkıştırılmış yoğunluğu sırasıyla $830 \mathrm{~kg} . \mathrm{m}-3$ ve 910 kg.m-3 olarak hesaplanmıştır. Hausner oranı 1.10 olarak ölçülmüştür ki bu da serbest akış özelliğine işaret etmektedir. Protein ekstraktı ilavesinin \%6.5'ten 13'e arttırlması, ekmek hacminin ekmek başına yaklaşık 283 mL'den 307 mL'ye artmasıyla sonuçlandığı tespit edilmiştir.

Anahtar kelimeler: Ekmek hacmi, nohut unu, FTIR, protein tozu

${ }^{*}$ Corresponding author / Yazışmalardan sorumlu yazar

๑1: ertan.ermis@gmail.com

(ग): (+90) 2126929722

县: (+90) 2126938229

Sebahat Sisman; ORCID no: 0000-0001-5917-5639

Busra Yagci; ORCID no: 0000-0001-6759-3857

Ertan Ermis; ORCID no: 0000-0002-1461-7357 


\section{INTRODUCTION}

Bread consumption has increased steadily in many parts of the developing world due to changing dietary habits and ever-evolving populations (Mtelisi Dube et al. 2020). In order to meet the growing consumers' expectations, it is necessary to improve the quality of the bread products. In addition, it is imperative to reduce the waste generated by throwing stale bread into the bin (Doğan et al. 2012).

The estimated production volume of bread is around 100 million tons per year, and around 10\% of total production is discarded worldwide due to poor quality, microbial spoilage and staling (Nionelli et al. 2020). Although bread is a staple food, it loses its desired properties due to staleness. Depending on the staleness of the bread, loss of aroma, loss of softness, and crumbling occur in the bread (Choi et al. 2008). While stale bread is still fit for consumption, the loss of texture and taste reduces consumer acceptance and poor sensory quality. Therefore, the stale bread is used as animal feed or thrown into the environment as waste (Doğan et al. 2012). However, the protein fraction of stale bread may serve as a suitable ingredient in the dough formulations to improve the protein content of composite flour mixtures.

In general, the protein content of bread is around 8-13\% (Turkomp 2019). Gluten is responsible for the extensibility and elasticity of the dough, and its functionality is closely related to processing quality of wheat dough (Tronsmo et al. 2003). Gluten can be added to weak wheat flours or flour mixtures to improve technological properties (i.e., dough processability and loaf volume). Bread made from flour containing a sufficient amount of gluten has a higher volume and slower staling rate than bread made with gluten-poor flour. Therefore, the protein fraction of stale bread can serve as a suitable ingredient for dough formulations.

Various studies have been conducted to extract protein fractions from various sources and used in dough formulations (Begum et al. 2011; Dua et al. 2009; Jiamyangyuen et al. 2005; Wieser 1998).
However, no information was found in the literature about protein extraction from stale bread and the evaluation of its functionality.

Since refined wheat flour lacks some dietary substances such as dietary fiber, and some essential amino acids (i.e., threonine and lysine) (Boye et al. 2010), enrichment with natural sources of functional compounds would be an effective means to improve its nutritional quality. Chickpea (Cicer arietinum L.) flour has high-quality protein containing well-balanced amino acid composition, dietary fibers, minerals, and other bioactive compounds and is a valuable ingredient for increasing the nutritional value of bread and bakery products (Gaur et al. 2015; Gobbetti et al. 2020; Man et al. 2015). Even though chickpea flour is a good source of protein, there is no gluten in its structure which causes some adverse effects on bread quality. Guardado-Félix et al. (2020) and Mohammed et al. (2012) reported that the addition of more than $10 \%$ of chickpea flour decreased bread volume and increased crumb firmness.

Taking into account the explanations given above, it was aimed to extract the protein fraction from stale bread, characterize its powder properties, and evaluate its potential to improve the quality of chickpea flour added wheat bread.

\section{MATERIAL and METHODS}

\section{Material}

The bread samples used in the tests were purchased from a local grocery store and kept at room temperature for two days to become stale. The chemicals and reagents were obtained from Sigma Aldrich (Darmstadt, Germany).

\section{Methods}

\section{Sample preparation}

Stale bread was cut into small pieces and placed in an oven to dry at $80^{\circ} \mathrm{C}$ for about four h until the moisture content was reduced to approximately $10 \%$. After drying, the bread pieces were grounded into powder using a coffee grinder (Sinbo SCM-2934). 


\section{Protein extraction}

The method reported by Joshi et al. (2011) was used to extract protein from stale bread. The dried and grounded stale bread samples were mixed with distilled water at a ratio of 1:15. The $\mathrm{pH}$ of the resulting mixture was adjusted to 9.50 by adding $1.0 \mathrm{M} \mathrm{NaOH}$ solution. The mixture was stirred at $750 \mathrm{rpm}$ with the aid of a magnetic stirrer for $60 \mathrm{~min}$ at room temperature. The mixture was then centrifuged at $12000 \mathrm{rpm}$ for 30 min. The $\mathrm{pH}$ of the supernatant was adjusted to 4.5 with $1 \mathrm{M} \mathrm{HCl}$. After the second centrifugation under the same conditions, the liquid phase was removed, and the pellet was collected. The pellet was placed in a glass petri dish and dried in an incubator at $35^{\circ} \mathrm{C}$ for approximately $36 \mathrm{~h}$.

\section{Evaluation of protein yield}

In order to evaluate the protein yield, the weight of the bread used in protein extraction was weighed, then the amount of protein obtained was given as $\%$ (wt/wt).

Determination of physicochemical properties of protein powder

\section{Protein content determination}

Protein content was measured by Bradford Assay method (Bradford 1976). To prepare $1 \mathrm{~L}$ Bradford reagent, $0.1 \mathrm{~g}$ of Coomassie Brilliant Blue G-250 was dissolved in 95\% ethanol, and $100 \mathrm{~mL}$ of $85 \%$ phosphoric acid was added, and the final volume was made up to $1 \mathrm{~L}$ with distilled water. The Bradford reagent prepared was filtered on filter paper. 1:1 ratio (protein powder: distilled water) of dispersion was prepared and passed through filter paper. Five-mL of Bradford reagent was added to $100 \mu \mathrm{L}$ of filtrate and left for $5 \mathrm{~min}$. Absorbance values at $595 \mathrm{~nm}$ were recorded, and the percent protein content was calculated using the standard calibration curve. The analysis was repeated three times. Bovine serum albumin (BSA) was used to prepare the standard calibration curve. BSA standard solution (1 $\mathrm{g} / \mathrm{mL}$ ) was diluted to $10,20,40,60$, and 100 $\mu \mathrm{g} / \mathrm{mL}$ with distilled water and a standard calibration curve was created by measuring the absorbance values using a UV-spectrophotometer (Shimadzu UV-1280, Kyoto, Japan).

\section{Water activity determination}

The protein powder was placed in the Novasina LabSwift water activity meter (Novasina, Lachen, Switzerland), and the measurement was performed according to the manufacturer's instructions.

\section{Moisture Determination}

The infrared moisture analyzer (Radwag, Radom, Poland) was employed for moisture analysis. Approximately $1 \mathrm{~g}$ of sample was placed on the weighing plate. The method was conducted based on the manufacturer's instructions.

\section{Determination of powder properties Bulk and tapped densities}

To determine the bulk density of the protein powder, $2 \mathrm{~g}$ of sample was transferred into a 10 $\mathrm{mL}$ graduated cylinder, and its volume was recorded. Bulk density was calculated by dividing the mass by volume $\left(\mathrm{kg} \cdot \mathrm{m}^{-3}\right)$. Then 150 taps (compression) were performed using a glass rod at a constant speed on the powder sample while in the graduated cylinder. The tapped density was calculated by dividing the mass by the volume of the sample after the taps (Ermis et al. 2018). The flow property of protein powder was evaluated by the Hausner ratio (HR) using Eq. 1 (Hausner 1967) and Table 1.

$H R=\varrho_{t} / \varrho_{b}$

Where $\varrho_{t}$ is tapped density and $\varrho_{b}$ is bulk density Table 1

Table 1. Classification of powder flow based on Hausner Ratio (Ermis et al. 2018)

\begin{tabular}{lc}
\hline Powder Flow Behavior & Hausner ratio \\
\hline Easy & $1.00-1.11$ \\
Good & $1.12-1.18$ \\
Satisfactory & $1.19-1.25$ \\
Poor & $1.26-1.34$ \\
Very poor & $1.35-1.45$ \\
\hline
\end{tabular}

\section{Wettability}

The powder sample $(1 \mathrm{~g})$ was left on the surface of a beaker filled with $400 \mathrm{~mL}$ of distilled water. The time required for the powder sample to submerge to the bottom of the beaker was recorded (Seth et al. 2016). 


\section{FTIR analysis}

FTIR spectrum of extracted protein powder was obtained to compare its chemical structure with gluten powder. The crystalline region of the ATR apparatus was cleaned with acetone prior to obtaining the background spectrum. Then, the powder sample was placed on the crystalline chamber of the device, and the spectrum was obtained between $4000-400 \mathrm{~cm}^{-1}$ by using an ATR-FTIR (Attenuated Total ReflectanceFourier Transform Infrared Spectroscopy) instrument (Shimadzu IRTracer-100, Kyoto, Japan).

\section{Bread production}

For the preparation of bread samples, the dough formulation reported by Begum et al. (2011) was used in this study with slight modifications.
Protein extracts were added into dough formulation at two different ratios (6.5 and 13\%) based on the total amount of flour mixture consisting of $60 \%$ wheat flour and $40 \%$ chickpea flour (Table 2). As the first step, instant dry yeast was dissolved in water, and then salt was added before transferring into the dough mixer. Other ingredients were transferred into the mixer, and the remaining water was added. The dough was mixed for the first two min at low speed and the next 10 minutes at medium speed. The dough was rested at room temperature for $45 \mathrm{~min}$. The dough is then divided into $100 \mathrm{~g}$ pieces, rounded, and proofed at $40{ }^{\circ} \mathrm{C}$ for $45 \mathrm{~min}$. The proofed dough was baked in the preheated oven for 20 min at $200{ }^{\circ} \mathrm{C}$. Bread volume was determined based on official methods of AACC 10-10.03 (AACC 2000).

Table 2. Ingredients used for preparing bread

\begin{tabular}{lcccc} 
Ingredients $(\mathrm{g} / 100 \mathrm{~g})$ & Control 1 & Control 2 & $\mathrm{A}$ & $\mathrm{B}$ \\
\hline Wheat flour & 65 & 39 & 36.6 & 34.2 \\
Chickpea flour & 0 & 26 & 24.4 & 22.8 \\
Water & 33 & 33 & 33 & 33 \\
Active dry yeast powder & 1 & 1 & 1 & 1 \\
Salt & 1 & 1 & 1 & 1 \\
Protein extract & 0 & 0 & 4 & 8 \\
\hline
\end{tabular}

\section{Statistical analysis}

The experiments were conducted in triplicate, and the mean values with standard deviations were calculated. Minitab 17 (Minitab Inc., Pennsylvania USA) was used to perform the statistical evaluations using one-way analysis of variance (ANOVA) and Tukey's multiple comparison test $(P<0.05)$.

\section{RESULTS and DISCUSSION \\ Evaluation of protein yield}

The yield of protein extract from stale bread was recorded as $1 \mathrm{~g}$ protein per $100 \mathrm{~g}$ of stale bread (Figure 1). Since the protein content of wheat bread is around $10 \%$, approximately $10 \%$ of total protein $(\mathrm{w} / \mathrm{w})$ could be extracted. The low yield might be due to the alteration of solubility behavior and the isoelectric point of protein fractions denatured during baking. Therefore, it was not possible to precipitate all the protein fractions at an isoelectric point of 4.5.

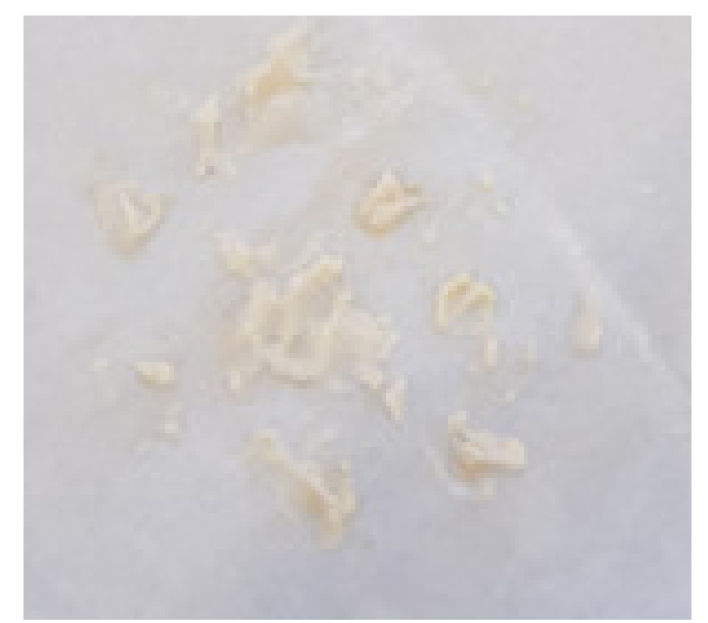

Figure 1. View of extracted protein from stale bread 


\section{Powder properties}

The water activity, moisture content, bulk density, tapped density, Hausner ratio, and the wettability properties were determined as $0.58,5.55 \%, 830$ $\mathrm{kg} \mathrm{m}^{-3}, 910 \mathrm{~kg} \mathrm{~m}^{-3}, 1.10$, and $816 \mathrm{~s}$, respectively. Moisture content and water activity are parameters that affect powder behavior, such as powder flow and storage stability. Water activity is more related to the food's physical, chemical, and biological properties than its moisture content. It is an important parameter that affects various food properties such as texture, color, and microbial growth. Generally, powders stored at low $a_{w}$ values and low temperatures retain their free-flowing properties, while stickiness and caking may occur at high $\mathrm{a}_{\mathrm{w}}$ and temperature values (García-Tejeda et al. 2019).

Moisture content and water activity values were found at safe levels to ensure storage and microbial stability. In order to ensure microbial stability in foods, the water activity value must be below 0.6. Also, moisture content should be below $10 \%$ to preserve the food for a more extended period while preserving its quality properties (Dirim and Talih 2018).

The wettability of the protein powder was measured as $816 \mathrm{~s}(13.6 \mathrm{~min})$ in this study. The wettability is an important physical property to be used in bread making due to its effect on dough development (Blancher et al. 2005). The wettability time gives information about the hydrophilic property of the powder material (Dirim and Talih 2018). A study observed that the wettability time of milk protein isolate was more than one h (Ji et al. 2016). According to Ji et al. (2016), powders showing wettability greater than 120 seconds are considered non-wettable. Thus, it can be stated that the protein powder obtained from stale bread by the alkali extractionisoelectric precipitation method is non-wettable.

Bulk density is a parameter that plays a role in transporting and packaging powder products. High bulk density is a desired feature as it will provide lower packaging and transportation costs (Dirim and Talih 2018). The ratio between tapped density and bulk density is determined as the
Hausner ratio. HR was calculated as 1.10, indicating easy flow behavior (Table 1).

\section{FTIR properties}

The chemical structure of the protein extract was examined by a FTIR spectrometer (Figure 2). Gluten standard was used as the reference material. The robust transmissions at $1653 \mathrm{~cm}^{-1}$ at $1748 \mathrm{~cm}^{-1}$ show $\mathrm{C}=\mathrm{N}$ and $\mathrm{C}=\mathrm{O}$ bonds, respectively. Peaks at $2800-2900 \mathrm{~cm}^{-1}$ region are assigned to a symmetrical and asymmetrical stretching of $\mathrm{CH}_{2}$ and $\mathrm{CH}_{3}$ groups. An Amide I band and an N-H intense stretching can be found at $2924 \mathrm{~cm}^{-1}$. C-H bonds at $2855 \mathrm{~cm}^{-1}$ clearly show us the presence of protein fractions. Amir et al. (2013) observed two main absorption bands, amide I and amide II, at approximately 1660 $\mathrm{cm}^{-1}$ and $1550 \mathrm{~cm}^{-1}$, respectively. The amide I peak centered around $1652 \mathrm{~cm}^{-1}$ in Figure 2 was similar to the findings of Lin et al. (2021) and Nawrocka et al. (2018). The FTIR data revealed differences in amide I and amide II peak intensities of extracted protein and gluten. Similarly, the peak intensities within the 750-1250 $\mathrm{cm}^{-1}$ region show differences in chemical properties. These differences might be attributed to the denaturation of proteins during baking and the existence of some impurities such as polysaccharides in extracted protein (Nawrocka et al. 2018).

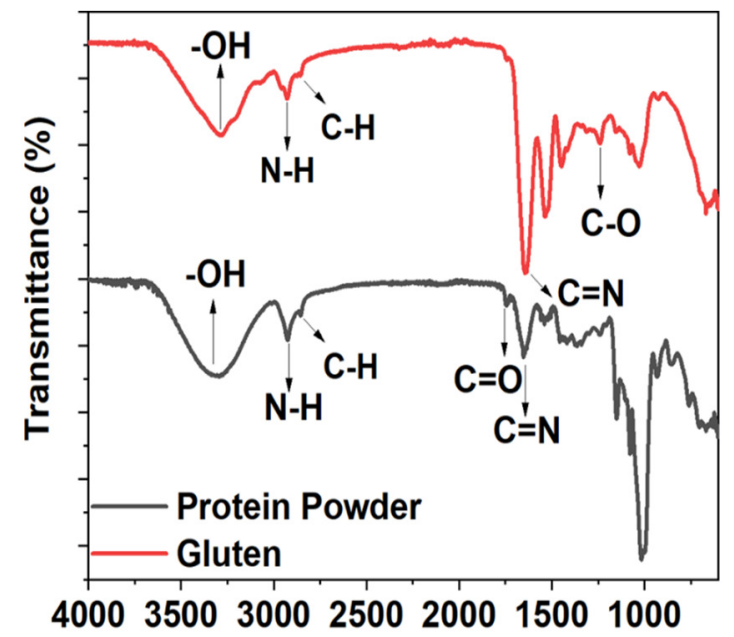

Figure 2. FTIR spectra of the extracted protein and gluten standard 


\section{Evaluation of loaf volume}

The loaf volume is an essential physical attribute in assessing bread quality. It is affected by the chemical structure of flour (i.e., gluten quality and content, amount of damaged starch) (Araki et al. 2009) and conditions applied during processing steps such as milling, mixing, kneading, fermentation, and baking. Assessment of bread loaf volume is a helpful way to determine the differences in the functionality of extracted proteins (Jiamyangyuen et al. 2005). The obtained protein powder was added to the bread formulations at $6.5 \%$ and $13 \%$ concentrations (based on total flour weight). The loaf volumes are reported in Table 3. The volume of Control 1 (prepared using 100\% wheat flour) and Control 2 (prepared using 60\% wheat flour $+40 \%$ chickpea flour mixture) bread samples were measured as $307.33 \pm 2.0$ and $282.67 \pm 5.33 \mathrm{~mL}$, respectively. The loaf volume of Control 2 bread was smaller when compared to those of bread samples $A$ and B. Increasing the protein added resulted in improved loaf volume by approximately 10 and $20 \%$ for $\mathrm{A}$ and $\mathrm{B}$, respectively (Figure 3 ). This increase could be attributed to the addition of protein powder extracted from stale bread.

Table 3. The volume of bread samples

\begin{tabular}{ll}
\hline Sample & Volume $(\mathrm{mL})$ \\
\hline Control 1 & $307.33 \pm 2.00 \mathrm{c}$ \\
Control 2 & $282.67 \pm 5.33 \mathrm{~d}$ \\
$\mathrm{~A}$ & $312.67 \pm 3.33 \mathrm{~b}$ \\
$\mathrm{~B}$ & $342.00 \pm 4.67 \mathrm{a}$ \\
\hline
\end{tabular}

Control 1: $100 \%$ wheat flour

Control 2: $60 \%$ wheat flour, $40 \%$ chickpea flour

A: $60 \%$ wheat flour $+40 \%$ chickpea flour $+6.5 \%$ protein,

B: $60 \%$ wheat flour $+40 \%$ chickpea flour $+13 \%$ protein

Values shown with different letters in the same column are statistically different $(P<0.05)$

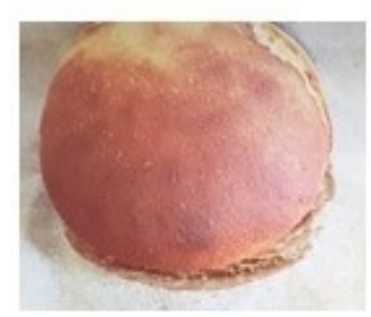

Control 1

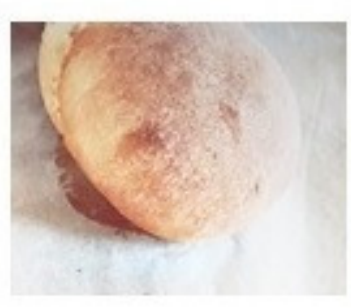

Control 2

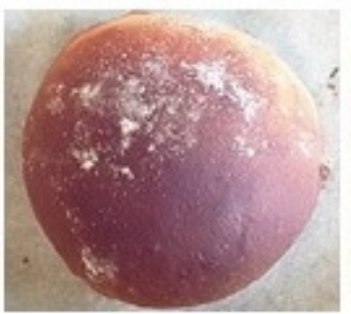

A

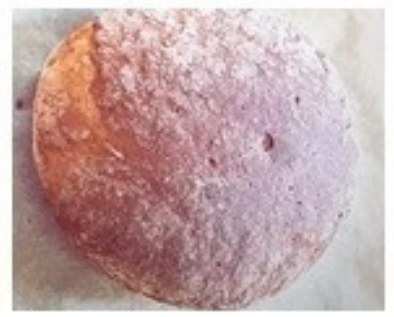

B

Figure 3. View of bread samples. Control 1: 100\% wheat flour, Control 2: 60\% wheat flour $+40 \%$ chickpea flour, A: $60 \%$ wheat flour $+40 \%$ chickpea flour $+6.5 \%$ extracted protein, B: $60 \%$ wheat flour $+40 \%$ chickpea flour $+13 \%$ extracted protein

\section{CONCLUSION}

In this study, protein extraction was made from stale bread by the isoelectric precipitation method, and it was aimed to increase the bread volume by adding into the mixtures of chickpea flour and wheat flour. Around $10 \%$ of the total protein could be extracted from stale bread and dried to produce protein powder. The powder had around $10 \%$ moisture and showed freeflowing behavior. FTIR analysis of protein extract exhibited similar spectra of the gluten standard. Adding $8 \mathrm{~g}$ extracted protein caused around 10\% and $20 \%$ volume increase in the wheat bread and chickpea flour added wheat bread, respectively. The data obtained in this study are promising and provide a scientific basis for further studies. Future studies should focus on improving protein extraction yield from stale bread by using different extraction methods and optimization of extraction conditions should be studied. 


\section{ACKNOWLEDGEMENTS}

This project was financially supported by The Scientific and Technological Research Council of Turkey (Project no: 1919B011902714).

\section{CONFLICT OF INTEREST}

The authors declare no conflict of interest.

\section{AUTHORS CONTRIBUTIONS}

Sebahat Şişman performed investigation, formal analysis and writing-original draft. Büşra Yağc1 helped in investigation, and formal analysis. Ertan Ermiş was supervisor and guided the project, performed final writing-review \& editing.

\section{REFERENCES}

AACC. (2000). American Association of Cereal Chemists, Approved Methods of the AACC, 10th ed. Methods 38-10, 38-20, 38-12A, 55-31, 66-50, 76-31, 80-60. St. Paul, MN.

Amir, R. M., Anjum, F. M., Khan, M. I., Khan, M. R., Pasha, I., Nadeem, M. (2013). Application of Fourier transform infrared (FTIR) spectroscopy for the identification of wheat varieties. J Food Sci Technol, 50(5), 1018-1023. https://doi.org/ $10.1007 /$ s13197-011-0424-y

Araki, E., Ikeda, T. M., Ashida, K., Takata, K., Yanaka, M., Iida, S. (2009). Effects of rice flour properties on specific loaf volume of one-loaf bread made from rice flour with wheat vital gluten. Food Sci Technol Res, 15(4), 439-448. https:// doi.org/10.3136/fstr.15.439

Begum, R., Rakshit, S. K., Rahman, S. M. M. (2011). Protein fortification and use of cassava flour for bread formulation. Int J Food Prop, 14(1), 185-198. 10942910903160406

Blancher, G., Morel, M. H., Gastaldi, E., Cuq, B. (2005). Determination of surface tension properties of wheat endosperms, wheat flours, and wheat glutens. Cereal Chem, 82(2), 158-165. https://doi.org/10.1094/CC-82-0158

Boye, J., Zare, F., Pletch, A. (2010). Pulse proteins: Processing, characterization, functional properties and applications in food and feed. Food Res Int, 43(2), 414-431. https://doi.org/10.1016/ j.foodres.2009.09.003
Bradford, M. (1976). A rapid and sensitive method for the quantitation of microgram quantities of protein utilizing the principle of protein-dye binding. Anal Biochem, 72(1-2), 248254. https://doi.org/10.1006/abio.1976.9999

Choi, Y. J., Ahn, S. C., Choi, H. S., Hwang, D. K., Kim, B. Y., Baik, M. Y. (2008). Role of water in bread staling: A review. Food Sci Biotechnol, 17(6), 1139-1145.

Dirim, S. N., Talih, M. (2018). Kurutma yardımc1 maddelerinin dondurarak kurutulmuş taflan tozlarının özellikleri üzerine etkisi. GID $A, 43$, 461-475. https://doi.org/10.15237/gida. GD17109

Doğan, I. S., Yildiz, Ö., Taşan, B. (2012). Determination of the bread-making quality of flours using an automatic bread machine. Turk $J$ Agric For, 36(5), 608-618. https://doi.org/ 10.3906/tar-1202-48

Dua, S., Lukow, O. M., Humphreys, G., Adams, K. (2009). Effect of extraction methods and wheat cultivars on gluten functionality. The Open Food Science Journal, 3, 84-92. https://doi.org/10.2174/1874256400903010084

Ermis, E., Güner, K. Ö., Yilmaz, M. T. (2018). Characterization of hazelnut milk powders: a comparison of spray-drying and freeze-drying. Int $J$ Food Eng, 14, 11-12 https://doi.org/ 10.1515/ijfe-2018-0085

García-Tejeda, Y. V., García-Armenta, E., Martínez-Audelo, J. M., Barrera-Figueroa, V. (2019). Determination of the structural stability of a premix powder through the critical water activity. J. Food Meas Charact, 13(2), 1323-1332. https://doi.org/10.1007/s11694-019-00047-1

Gaur, P. M., Samineni, S., Sajja, S., Chibbar, R. N. (2015). Achievements and challenges in improving nutritional quality of chickpea. Legume Perspectives, 09(9), 31-33.

Gobbetti, M., De Angelis, M., Di Cagno, R., Polo, A., Rizzello, C. G. (2020). The sourdough fermentation is the powerful process to exploit the potential of legumes, pseudo-cereals and milling by-products in baking industry. Crit Rev Food Sci Nutr, 60(13), 2158-2173. 
https://doi.org/10.1080/10408398.2019.163175 3

Guardado-Félix, D., Lazo-Vélez, M. A., PérezCarrillo, E., Panata-Saquicili, D. E., SernaSaldívar, S. O. (2020). Effect of partial replacement of wheat flour with sprouted chickpea flours with or without selenium on physicochemical, sensory, antioxidant and protein quality of yeast-leavened breads. LWT, 129, 109517. https://doi.org/10.1016/j.lwt.2020. 109517

Hausner, H. H. (1967). Friction Conditions in a Mass of Metal Powder. Int J Powder Met, 3, 7-13.

Ji, J., Fitzpatrick, J., Cronin, K., Maguire, P., Zhang, H., Miao, S. (2016). Rehydration behaviours of high protein dairy powders: The influence of agglomeration on wettability, dispersibility and solubility. Food Hydrocoll, 58, 194-203. https://doi.org/10.1016/j.foodhyd. 2016.02.030

Jiamyangyuen, S., Srijesdaruk, V., Harper, W. (2005). Extraction of rice bran protein concentrate and its application in bread. Songklanakarin J Sci Technol, 27(1), 55-64.

Lin, H., Bean, S. R., Tilley, M., Peiris, K. H. S., Brabec, D. (2021). Qualitative and quantitative analysis of sorghum grain composition including protein and tannins using atr-ftur spectroscopy. Food Anal Method, 14(2), 268-279. https://doi.org/10.1007/s12161-020-01874-5

Man, S., Păucean, A., Muste, S., Pop, A. (2015). Effect of the chickpea (cicer arietinum 1.) Flour addition on physicochemical properties of wheat bread. Bulletin of University of Agricultural Sciences and Veterinary Medicine Cluj-Napoca. Food Sci Technol, 72(1). https://doi.org/ 10.15835/buasvmcn-fst:11023

Mohammed, I., Ahmed, A. R., Senge, B. (2012). Dough rheology and bread quality of wheatchickpea flour blends. Ind Crops Prod, 36(1), 196202. 2011.09.006
Mtelisi Dube, N., Xu, F., Zhao, R. (2020). The efficacy of sorghum flour addition on dough rheological properties and bread quality: A short review. Grain Oil Sci Technol, 3(4), 164-171. https://doi.org/10.1016/j.gaost.2020.08.001

Nawrocka, A., Krekora, M., Niewiadomski, Z., Miś, A. (2018). FTIR studies of gluten matrix dehydration after fibre polysaccharide addition. Food Chem, 252, 198-206. https://doi.org/ 10.1016/j.foodchem.2018.01.110

Nionelli, Luana, Wang, Y, Pontonio, E, Immonen, M, Rizzello, C G, Maina, H. N, Katine, K., Coda,R. (2020). Antifungal effect of bioprocessed surplus bread as ingredient for bread-making: Identification of active compounds and impact on shelf-life. Food Cont, 118. https://doi.org/10.1016/j.foodcont. 2020.107437

Seth, D., Mishra, H. N., Deka, S. C. (2016). Functional and reconstitution properties of spraydried sweetened yogurt powder as influenced by processing conditions. Int $J$ Food Prop, 20(7), 1603-1611. https://doi.org/10.1080/10942912. 2016.1214965

Tronsmo, K. M., Magnus, E. M., Baardseth, P., Schofield, J. D., Aamodt, A., Færgestad, E. M. (2003). Comparison of small and large deformation rheological properties of wheat dough and gluten. Cereal Chem, 80(5), 587-595. https://doi.org/10.1094/cchem.2003.80.5.587

Turkomp. (2019). Turkish Food Composition Database. http://www.turkomp.gov.tr/food-280

Wieser, H. (1998). Investigations on the extractability of gluten proteins from wheat bread in comparison with flour. Z Lebensm Unters Forsch, 207(2), 128-132. https://doi.org/10.1007/ s002170050306 